\title{
Energy labs face uncertain future after US elections
}

San Francisco. Researchers at California's two largest government-funded research laboratories fear that they may face major budget cuts - or possibly even elimination - under the Republican-dominated Congress elected last month.

A major part of the platform on which the Republicans won control of Congress was a promise to balance the federal budget, cut taxes and slash government spending. According to both Republican and Democrat sources in Washington, this could result in considerable pressure on the Lawrence Berkeley and Lawrence Livermore laboratories, despite the new majority party's commitment to basic science.

Supporters of the laboratories fear that even if the Republicans keep their promise to restore military spending, this will do little for research, because most of the money will go directly to improving the readiness of the armed forces.

Some Republican officials have already indicated that they would like to break up the \$18.5-billion Department of Energy (DoE), which manages both laboratories through the University of California. Representative John Kasich (Republican, Ohio), although a supporter of defence spending, has in the past proposed closing the federal laboratories on the grounds that they are no longer needed. He is expected to become chair of the powerful House of Representatives Budget Committee.

The DoE, which was created in 1977 by former President Jimmy Carter and took over the laboratories of the former Atomic Energy Commission, has come under attack before. But it may not survive this time.

Diminishing concern about the need to separate weapons research from the military - initially intended to enhance the security surrounding research and development on nuclear weapons - means that it would be easier to move such work to the Department of Defense, and to divide the DoE's other programmes among other agencies. Such a change would have a dramatic effect on Lawrence Berkeley and Lawrence Livermore, which rely on the energy department for 80 per cent of their funding.

Nuclear weapons research - which accounts for about half of Lawrence Livermore's \$868-million operating budget - would probably move to the defence department, with the rest split between agencies. The laboratory might then find itself with less powerful political support against further budget cutting than in the past.

Other programmes likely to be closely scrutinized are those aimed at transferring technology to industry. Under the Clinton administration, these have grown in impor- tance at both laboratories, as a means of keeping research teams intact and boosting the US economy.

But many Republicans view such programmes as government interference in the market place. The Advanced Technology Program, organized by the National Institute of Standards and Technology (NIST), has been targeted for particular attack.

Research programmes on renewable energy, energy efficiency and climate change could be cut back severely, although the

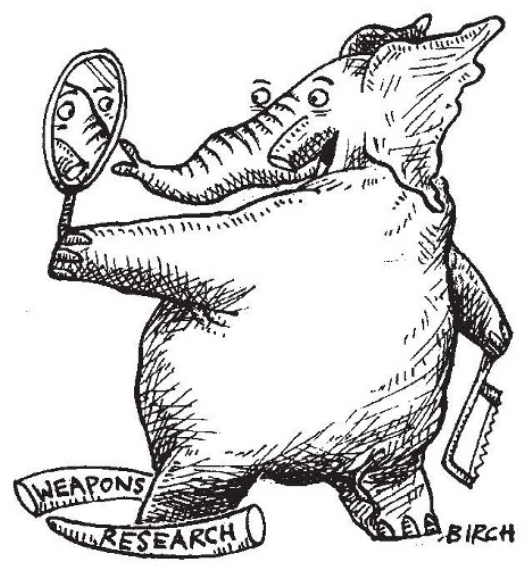

human genome programme is likely to be spared. With industry's help, the laboratories hope to persuade the new Congress that technology transfer is not the same as industrial subsidy, and deserves continued support.

The severity of the cuts will become apparent during the first half of next year as Congress shapes the federal budget for the year starting 1st October 1995, on the basis of a budget proposal due from President Bill Clinton in February.

A report on the management of the weapons laboratories, commissioned last year by Energy Secretary Hazel O'Leary from a committee chaired by Robert Galvin, chairman of the electronics company Motorola, is due for publication in February, and is also likely to affect the budget outcome (see Nature 371, 368; 1994). Although the task force preparing it has not revealed its thinking, a source close to the laboratories says he feels the group was impressed by their research, but worried about the quality of the DoE supervision of the laboratories.

Additional uncertainty over the future of the laboratories arises from the new and unknown priorities of those tipped to chair the congressional committees responsible for their funding. But some of the core defence missions of Lawrence Livermore and the basic research work at Lawrence Berkeley could still find support among Republicans.

\section{Italian drug firms rethink ban on conference support}

Munich. Italian pharmaceutical companies look likely to reverse a temporary ban on the commercial sponsorship of scientific congresses following complaints from the scientific community.

In Italy, about a third of the funding for scientific conferences comes from industrial sponsors, and scientists fear that some meetings planned for next year may have to be cancelled, including the first European Congress of Pharmacology, scheduled to be held in Milan next June.

The ban was introduced as part of the industry's response to health reforms introduced by the government in January. The reforms were aimed in particular at reducing the prices of key drugs, and at limiting the number of drugs whose purchase is reimbursed by the state.

Following a drastic fall in profits, Farmindustria, the umbrella association representing the Italian pharmaceutical industry, decided in October on a six-month ban on all promotional activities. If the financial situation facing the industry does not improve, warns Farmindustria spokesman Cesare Fassari, the ban may be extended.

Drug companies have agreed to stop advertising in medical journals and to cut the distribution of free drug samples to doctors by 60 per cent. They have also decided to stop sponsoring scientific congresses which such companies often use as a way of promoting their products - for the first half of 1995.

By supporting a uniform ban across the industry, individual drug companies hope that they will be able to save money without losing their competitive edge in the Italian market. They also hope to regain public confidence in the industry and thus discourage any further cuts in drug prices, after corruption scandals last year (see Nature 364, 658; 1993).

But scientists are upset that genuine scientific conferences, which have nothing to do with product promotion, are included in the ban. After a meeting with scientists several weeks ago, Farmindustria is now considering reversing the ban. A small advisory committee representing scientific societies will assess congresses seeking sponsorship, and will make recommendations to Farmindustria to fund those with genuine scientific content.

Gianni Marini, vice-president of Farmindustria, confirms that the board of Farmindustria will soon decide whether to make exceptions for meetings with a genuine scientific content which have already been planned. "I am in favour," he says. "We cannot interfere with scientific communication."

Toni Feder 